\title{
Effect of supplementation of feed with Flaxseed (Linumusitatisimum) oil on libido and semen quality of Nilli-Ravi buffalo bulls
}

\author{
Syed Mazhar Hussain Shah, Shujait Ali, Muhammad Zubair*, Huma Jamil and Nazir Ahmad
}

\begin{abstract}
Background: The current study was designed to investigate the effect of supplementation of Flaxseed (Linumusitatisimum) oil on libido and semen quality of Nilli-Ravi buffalo bulls.

Methods: In this study, 12 adult healthy bulls kept at the Semen Production Unit, Qadirabad district Sahiwal, were used. These bulls were divided into three equal groups, A, B and C. Group A was kept as control, while in groups B and $C$ supplementation of feed was provided by using flaxseed oil @125 ml/day and $250 \mathrm{ml} /$ day,respectively for 12 weeks. Two ejaculates per animal were collected at 0 day then 5th, 6th, 7th, 8th, 9th, 10th, 11th and 12th week of treatment. In this way a total 216 samples were taken, and each semen sample was evaluated for color, volume, mass activity, percent motility, sperm cell concentration per $\mathrm{ml}$, percentage of live sperm, and plasma membrane integrity. Libido of bulls was also evaluated before every collection.
\end{abstract}

Results: Analysis of data revealed that these parameters were significantly $(P<0.01)$ increased in flax oil treated animals as compared to control.

Conclusion: It was concluded from the present study that flax seed oil has beneficial effects on reproductive health of buffalo bull.

Keywords: Semen, Flax seed and breeding bulls

\section{Background}

Male contributes $50 \%$ of the herd and importance of male in genetic improvement of livestock cannot be denied. Genetic potential of a male is commonly exploited through artificial insemination. Reproductive capacity of males is judged by sperm production and success of artificial insemination depends upon number and quality of sperms in the ejaculate [6]. Semen is collected from genetically superior animals. In addition to other factors, volume of semen, sperm concentration, motility and number of normal sperm have great importance in conception.

In Mammalian sperm, lipids especially n-3 fatty acids are dominantly present [24]. These fatty acids are involved in motility of sperm, integrity of sperm membrane and protection of sperm from cold shock [25].

\footnotetext{
* Correspondence: drzubairabbasi@gmail.com

Department of Theriogenology, Faculty of Veterinary Sciences, University of

Agriculture Faisalabad, Faisalabad, Pakistan
}

Animals are unable to synthesize the $n-3$ and $n-6$ fatty acids in their body as they do not have sufficient amount of fatty acid denaturize enzymes. Therefore, these fatty acids need to be taken by dietary sources [31]. Previous studies have shown that those fatty acids which are present in diet are also a part of sperm in human [8] and in farm animals [16]. Moreover, ration having fatty acids in diet improves value of post thawed buffalo bull semen [1].

Docosahexaenoic acid has been shown to increases serum testosterone level and sperm motility in man [8], boar [26], goat [9] and sheep [30] and flaxseed is a source of docosahexaenoic acid. Omega -3 fatty acids are necessary for cell membrane integrity and fitness of brain and eyes [8]. Main component of flaxseed is lignin, which contains plant estrogen and antioxidants and has protective effect on sex hormone metabolism [2]. 
Little information is available with regard to the effect of dietary flax seed oil supplementation and fertility of buffalo bulls during heat stress . The objective of present study was to investigate the effect of flaxseed oil supplementation on libido and semen quality parameters of Nilli-Ravi buffalo bulls.

\section{Methods}

\section{Experimental animals}

A total of 12 adult Nilli-Ravi buffalo bulls with clinically normal reproductive tract kept at the Semen Production Unit Qadirabad district Sahiwal, Pakistan were used in this study. These bulls were routinely used for semen collection. Animals were randomly divided into 3 equal groups A, B and C. Group A was kept as control while, group $B$ and $C$ was supplemented flaxseed oil drenched orally with dose of $125 \mathrm{ml}$ and $250 \mathrm{ml}$ respectively. All these treatments were continued for consecutive 12 weeks. The study period was from mid April to mid July, 2015. Semen was collected by artificial vagina at day 0 then 5 th, 6th, 7th, 8th, 9th, 10th, 11th and 12th week of treatment. Two ejaculates per animal were collected on each collection day.

\section{Parameters examined}

Libido of each bull was assessed by mating behavior of bulls. Mating behavior was videotaped using video camera and video recorder. By watching videotapes libido in terms of reaction time to first semen collection was recorded [17]. Each ejaculate was evaluated for color, volume, mass activity, percent motility, sperm concentration, live sperm, and plasma membrane integrity. To examine mass activity, a small drop of semen was placed on pre warmed glass slide with glass rod and examined under microscope. On the base of

Table 1 Mean values ( \pm SE) of Libido collected from bulls of control and treatment groups on different weeks

\begin{tabular}{lllll}
\hline Weeks of & Group & & & $\begin{array}{l}\text { Over all } \\
\text { Treatments }\end{array}$ \\
\cline { 2 - 4 } & A (Control) & B (Treatment 1) & C (Treatment 2) & Mean \\
\hline 0 & $7.50 \pm 0.50 \mathrm{a}$ & $7.25 \pm 0.48 \mathrm{ab}$ & $7.50 \pm 0.29 \mathrm{a}$ & $7.42 \pm 0.23 \mathrm{~A}$ \\
5 & $7.50 \pm 0.65 \mathrm{a}$ & $4.75 \pm 0.25 \mathrm{cde}$ & $4.25 \pm 0.48 \mathrm{e}$ & $5.50 \pm 0.50 \mathrm{~B}$ \\
6 & $6.75 \pm 0.48 \mathrm{a}-\mathrm{d}$ & $5.00 \pm 0.41 \mathrm{~b}-\mathrm{e}$ & $4.75 \pm 0.48 \mathrm{cde}$ & $5.50 \pm 0.36 \mathrm{~B}$ \\
7 & $7.25 \pm 0.48 \mathrm{ab}$ & $4.50 \pm 0.29 \mathrm{de}$ & $4.25 \pm 0.25 \mathrm{e}$ & $5.33 \pm 0.45 \mathrm{~B}$ \\
8 & $7.50 \pm 0.29 \mathrm{a}$ & $4.50 \pm 0.29 \mathrm{de}$ & $4.25 \pm 0.48 \mathrm{e}$ & $5.42 \pm 0.48 \mathrm{~B}$ \\
9 & $7.00 \pm 0.71 \mathrm{abc}$ & $4.00 \pm 0.41 \mathrm{e}$ & $4.00 \pm 0.41 \mathrm{e}$ & $5.00 \pm 0.51 \mathrm{~B}$ \\
10 & $7.25 \pm 0.48 \mathrm{ab}$ & $4.25 \pm 0.48 \mathrm{e}$ & $4.00 \pm 0.41 \mathrm{e}$ & $5.17 \pm 0.51 \mathrm{~B}$ \\
11 & $6.75 \pm 0.25 \mathrm{a}-\mathrm{d}$ & $4.00 \pm 0.41 \mathrm{e}$ & $4.00 \pm 0.41 \mathrm{e}$ & $4.92 \pm 0.43 \mathrm{~B}$ \\
12 & $7.00 \pm 0.41 \mathrm{abc}$ & $4.00 \pm 0.41 \mathrm{e}$ & $4.00 \pm 0.41 \mathrm{e}$ & $5.00 \pm 0.48 \mathrm{~B}$ \\
Mean & $7.17 \pm 0.15 \mathrm{~A}$ & $4.69 \pm 0.20 \mathrm{~B}$ & $4.56 \pm 0.22 \mathrm{~B}$ & \\
\hline
\end{tabular}

Means sharing similar letters in a row or in a column are statistically nonsignificant $(P>0.05)$. Small letters represent comparison among interaction means and capital letters are used for overall means
Table 2 Mean values ( \pm SE) of semen volume $(\mathrm{ml})$ collected from bulls of control and treatment groups on different weeks

\begin{tabular}{lllll}
\hline \multirow{2}{*}{$\begin{array}{l}\text { Weeks of } \\
\text { Treatment }\end{array}$} & Group & & \multicolumn{2}{l}{$\begin{array}{l}\text { Overall } \\
\text { Mean }\end{array}$} \\
\cline { 2 - 5 } & $\mathrm{A}$ (Control) & $\mathrm{B}$ (Treatment 1) & $\mathrm{C}$ (Treatment 2) & \\
\hline 0 & $5.25 \pm 0.95 \mathrm{~d}-\mathrm{h}$ & $4.50 \pm 0.29 \mathrm{fgh}$ & $3.75 \pm 0.48 \mathrm{~h}$ & $4.50 \pm 0.38 \mathrm{D}$ \\
5 & $3.38 \pm 0.24 \mathrm{~h}$ & $5.00 \pm 0.41 \mathrm{~d}-\mathrm{h}$ & $4.50 \pm 0.29 \mathrm{fgh}$ & $4.29 \pm 0.26 \mathrm{D}$ \\
6 & $3.75 \pm 0.48 \mathrm{~h}$ & $5.75 \pm 0.14 \mathrm{c}-\mathrm{g}$ & $4.75 \pm 0.25 \mathrm{e}-\mathrm{h}$ & $4.75 \pm 0.30 \mathrm{CD}$ \\
7 & $4.00 \pm 0.41 \mathrm{gh}$ & $6.50 \pm 0.20 \mathrm{a}-\mathrm{e}$ & $6.00 \pm 0.41 \mathrm{~b}-\mathrm{f}$ & $5.50 \pm 0.37 \mathrm{BC}$ \\
8 & $3.63 \pm 0.38 \mathrm{~h}$ & $6.50 \pm 0.20 \mathrm{a}-\mathrm{e}$ & $6.75 \pm 0.32 \mathrm{a}-\mathrm{d}$ & $5.63 \pm 0.46 \mathrm{ABC}$ \\
9 & $3.63 \pm 0.38 \mathrm{~h}$ & $7.38 \pm 0.24 \mathrm{abc}$ & $7.38 \pm 0.24 \mathrm{abc}$ & $6.13 \pm 0.55 \mathrm{AB}$ \\
10 & $3.75 \pm 0.48 \mathrm{~h}$ & $7.63 \pm 0.24 \mathrm{abc}$ & $7.88 \pm 0.13 \mathrm{ab}$ & $6.42 \pm 0.59 \mathrm{AB}$ \\
11 & $3.63 \pm 0.38 \mathrm{~h}$ & $7.88 \pm 0.31 \mathrm{ab}$ & $8.00 \pm 0.20 \mathrm{a}$ & $6.50 \pm 0.63 \mathrm{~A}$ \\
12 & $3.63 \pm 0.24 \mathrm{~h}$ & $7.88 \pm 0.13 \mathrm{ab}$ & $8.13 \pm 0.13 \mathrm{a}$ & $6.54 \pm 0.63 \mathrm{~A}$ \\
Mean & $3.85 \pm 0.17 \mathrm{~B}$ & $6.56 \pm 0.21 \mathrm{~A}$ & $6.35 \pm 0.28 \mathrm{~A}$ & \\
\hline
\end{tabular}

Means sharing similar letters in a row or in a column are statistically nonsignificant $(P>0.05)$. Small letters represent comparison among interaction means and capital letters are used for overall means

wave pattern, mass activity score from0 to 5 was assigned to each sample [27]. To examine motility of spermatozoa, a drop of semen was placed on glass slide and mixed with a drop of $2.9 \%$ sodium citrate. Slide was examined under 200X magnification. Sperm concentration was directly determined using Accucell Bovine Photometer. Sperm membrane functional integrity was determined by hypo-osmotic swelling test (HOST) which is based on semi permeability of cell membrane. The hypo-osmotic solution (150 mosm/L) was prepared as described by [19]. Eosin-nigrosin staining was used to determine live perm percentage.

\section{Statistical analysis}

Mean values $( \pm$ SE) of various parameters for bulls of three groups were calculated. The differences in group

Table 3 Mean values ( \pm SE) of Mass Activity collected from bulls of control and treatment groups on different weeks

\begin{tabular}{lllll}
\hline $\begin{array}{l}\text { Weeks of } \\
\text { Treatment }\end{array}$ & Group & & & \multicolumn{2}{l}{$\begin{array}{l}\text { Overall } \\
\text { Mean }\end{array}$} \\
\cline { 2 - 5 } & $\mathrm{A}$ (Control) & $\mathrm{B}$ (Treatment 1) & $\mathrm{B}$ (Treatment 2) & \\
\hline 0 & $1.75 \pm 0.25 \mathrm{ef}$ & $1.50 \pm 0.29 \mathrm{f}$ & $1.50 \pm 0.29 \mathrm{f}$ & $1.58 \pm 0.15 \mathrm{E}$ \\
5 & $1.75 \pm 0.25 \mathrm{ef}$ & $2.25 \pm 0.25 \mathrm{def}$ & $2.00 \pm 0.00 \mathrm{def}$ & $2.00 \pm 0.12 \mathrm{DE}$ \\
6 & $2.00 \pm 0.00 \mathrm{def}$ & $2.25 \pm 0.25 \mathrm{def}$ & $2.00 \pm 0.00 \mathrm{def}$ & $2.08 \pm 0.08 \mathrm{CDE}$ \\
7 & $2.00 \pm 0.00 \mathrm{def}$ & $2.50 \pm 0.29 \mathrm{c}-\mathrm{f}$ & $2.50 \pm 0.29 \mathrm{c}-\mathrm{f}$ & $2.33 \pm 0.14 \mathrm{CD}$ \\
8 & $1.75 \pm 0.25 \mathrm{ef}$ & $2.50 \pm 0.29 \mathrm{c}-\mathrm{f}$ & $2.75 \pm 0.25 \mathrm{~b}-\mathrm{e}$ & $2.33 \pm 0.19 \mathrm{CD}$ \\
9 & $1.75 \pm 0.25 \mathrm{ef}$ & $3.00 \pm 0.00 \mathrm{a}-\mathrm{d}$ & $3.00 \pm 0.00 \mathrm{a}-\mathrm{d}$ & $2.58 \pm 0.19 \mathrm{BC}$ \\
10 & $2.00 \pm 0.00 \mathrm{def}$ & $3.50 \pm 0.29 \mathrm{abc}$ & $3.50 \pm 0.29 \mathrm{abc}$ & $3.00 \pm 0.25 \mathrm{AB}$ \\
11 & $2.00 \pm 0.00 \mathrm{def}$ & $3.75 \pm 0.25 \mathrm{ab}$ & $4.00 \pm 0.00 \mathrm{a}$ & $3.25 \pm 0.28 \mathrm{~A}$ \\
12 & $2.00 \pm 0.00 \mathrm{def}$ & $4.00 \pm 0.00 \mathrm{a}$ & $4.00 \pm 0.00 \mathrm{a}$ & $3.33 \pm 0.28 \mathrm{~A}$ \\
Mean & $1.89 \pm 0.05 \mathrm{~B}$ & $2.81 \pm 0.15 \mathrm{~A}$ & $2.81 \pm 0.15 \mathrm{~A}$ & \\
\hline
\end{tabular}

Means sharing similar letters in a row or in a column are statistically nonsignificant $(P>0.05)$. Small letters represent comparison among interaction means and capital letters are used for overall means 
Table 4 Mean values $( \pm S E)$ of Motility percentage collected from bulls of control and treatment groups on different weeks

\begin{tabular}{lllll}
\hline Weeks of Treatments & Group & & & \\
\cline { 2 - 4 } & A (Control) & B (Treatment 1) & C (Treatment 2) & \\
\hline 0 & $68.75 \pm 1.25 \mathrm{c}-\mathrm{f}$ & $65.00 \pm 2.04 \mathrm{ef}$ & $65.00 \pm 0.00 \mathrm{ef}$ & $66.25 \pm 0.90 \mathrm{C}$ \\
5 & $63.75 \pm 1.25 \mathrm{f}$ & $70.00 \pm 2.04 \mathrm{~b}-\mathrm{f}$ & $66.25 \pm 2.39 \mathrm{def}$ & $66.67 \pm 1.28 \mathrm{C}$ \\
6 & $67.50 \pm 1.44 \mathrm{def}$ & $68.75 \pm 1.25 \mathrm{c}-\mathrm{f}$ & $67.50 \pm 1.44 \mathrm{def}$ & $67.92 \pm 0.74 \mathrm{BC}$ \\
7 & $67.50 \pm 1.44 \mathrm{def}$ & $70.00 \pm 2.04 \mathrm{~b}-\mathrm{f}$ & $68.75 \pm 1.25 \mathrm{c}-\mathrm{f}$ & $68.75 \pm 0.90 \mathrm{BC}$ \\
8 & $66.25 \pm 2.39 \mathrm{def}$ & $73.75 \pm 1.25 \mathrm{a}-\mathrm{e}$ & $75.00 \pm 2.04 \mathrm{a}-\mathrm{d}$ & $71.67 \pm 1.55 \mathrm{AB}$ \\
9 & $66.25 \pm 2.39 \mathrm{def}$ & $77.50 \pm 1.44 \mathrm{abc}$ & $77.50 \pm 1.44 \mathrm{abc}$ & $73.75 \pm 1.86 \mathrm{~A}$ \\
10 & $66.25 \pm 2.39 \mathrm{def}$ & $77.50 \pm 1.44 \mathrm{abc}$ & $77.50 \pm 1.44 \mathrm{abc}$ & $73.75 \pm 1.86 \mathrm{~A}$ \\
11 & $63.75 \pm 2.39 \mathrm{f}$ & $78.75 \pm 1.25 \mathrm{ab}$ & $80.00 \pm 2.04 \mathrm{a}$ & $74.17 \pm 2.45 \mathrm{~A}$ \\
12 & $61.25 \pm 1.25 \mathrm{f}$ & $81.25 \pm 1.25 \mathrm{a}$ & $82.50 \pm 1.44 \mathrm{a}$ & $75.00 \pm 3.02 \mathrm{~A}$ \\
Mean & $65.69 \pm 0.67 \mathrm{~B}$ & $73.61 \pm 0.99 \mathrm{~A}$ & $73.33 \pm 1.14 \mathrm{~A}$ &
\end{tabular}

Means sharing similar letters in a row or in a column are statistically non-significant $(P>0.05)$. Small letters represent comparison among interaction means and capital letters are used for overall means

were compared by "Tukey test". The data was analyzed using SPSS software.

\section{Results}

Analysis of variance showed that there is $(P<0.01)$ improvement of libido in treated groups as compared to control. Interaction between weeks and groups was also significant (Table 1). Analysis of variance of Table 2 revealed that there was the significant effect of weeks and treatment on semen volume ( $p$ 0.01). Further analysis showed that semen volume for bulls of group B and C was $(p \quad 0.01)$ higher than the control. However, difference between group $\mathrm{B}$ and $\mathrm{C}$ was non-significant. The effect of weeks and treatment on semen mass activity of treated groups was significant $\left(\begin{array}{ll}p & 0.01\end{array}\right)$ higher as in Table 3. Likewise, weekly analysis of variance revealed that semen mass activity for bulls of group $B$ and $C$ was significantly higher than the control. However, there was non-significant difference between group B and C.

Analysis of variance indicated that motility percentage was highly significant $\left(\begin{array}{ll}P & 0.01\end{array}\right)$ in treated groups as compared to control. However, difference between group $\mathrm{B}$ and $\mathrm{C}$ was non-significant. Interaction between weeks and groups was also significant (Table 4). Analysis of variance reveled that sperm concentration is highly significant $(P<0.01)$ in both treated group as compared to control group (Table 5). However, difference between group $\mathrm{B}$ and $\mathrm{C}$ was non-significant. Interaction between weeks and groups was also significant. Mean value of live sperm percentage in control group A was lower as compared to $\mathrm{b}$ and $\mathrm{C}$. Analysis of variance showed that there was significant effects on treated group as compared to control (Table 6). Overall mean value for HOST in control group A was lower as compared to treated

Table 5 Mean values ( \pm SE) of Sperm Concentration (Million/ml) of semen collected from bulls of control and treatment groups on different weeks

\begin{tabular}{|c|c|c|c|c|}
\hline \multirow[t]{2}{*}{ Weeks of Treatments } & \multicolumn{3}{|l|}{ Group } & \multirow[t]{2}{*}{ Overall Mean } \\
\hline & A (Control) & B (Treatment 1) & C (Treatment 2) & \\
\hline 0 & $1626.8 \pm 38.0 \mathrm{~d}-\mathrm{g}$ & $1001.9 \pm 182.9 k$ & $1246.0 \pm 108.5$ h-k & $1291.5 \pm 101.3 \mathrm{~F}$ \\
\hline 5 & $1266.0 \pm 93.8 \mathrm{~g}-\mathrm{k}$ & $1429.8 \pm 29.1 f-j$ & $1354.0 \pm 24.9 f-k$ & $1349.9 \pm 036.6 \mathrm{EF}$ \\
\hline 6 & $1094.8 \pm 102.2 \mathrm{jk}$ & $1591.5 \pm 16.0 \mathrm{e}-\mathrm{h}$ & $1472.5 \pm 13.8 \mathrm{e}-\mathrm{i}$ & $1386.3 \pm 071.2 \mathrm{EF}$ \\
\hline 7 & $1176.0 \pm 41.6 \mathrm{ijk}$ & $1696.8 \pm 26.1 \mathrm{def}$ & $1644.0 \pm 39.4 \mathrm{def}$ & $1505.6 \pm 073.1 \mathrm{DE}$ \\
\hline 8 & $1171.3 \pm 92.8 \mathrm{ijk}$ & $1844.5 \pm 83.8 \mathrm{cde}$ & $1811.0 \pm 38.3 \mathrm{cde}$ & $1608.9 \pm 101.4 C D$ \\
\hline 9 & $1171.3 \pm 92.8 \mathrm{ijk}$ & $2071.3 \pm 56.2 a b c$ & $1988.5 \pm 39.2 \mathrm{bcd}$ & $1743.7 \pm 127.3 B C$ \\
\hline 10 & $1270.0 \pm 72.5 \mathrm{~g}-\mathrm{k}$ & $2356.0 \pm 47.7 a b$ & $2105.8 \pm 45.8 \mathrm{abc}$ & $1910.6 \pm 143.1 \mathrm{AB}$ \\
\hline 11 & $1243.3 \pm 52.8 \mathrm{~h}-\mathrm{k}$ & $2371.8 \pm 46.2 \mathrm{a}$ & $2299.0 \pm 59.4 a b$ & $1971.3 \pm 157.9 \mathrm{~A}$ \\
\hline 12 & $1196.3 \pm 46.5 \mathrm{ijk}$ & $2405.0 \pm 47.4 a$ & $2378.0 \pm 58.4 a$ & $1993.1 \pm 172.0 \mathrm{~A}$ \\
\hline Mean & $1246.2 \pm 32.7 \mathrm{~B}$ & $1863.2 \pm 80.2 \mathrm{~A}$ & $1811.0 \pm 67.3 \mathrm{~A}$ & \\
\hline
\end{tabular}

Means sharing similar letter in a row or in a column are statistically non-significant $(P>0.05)$. Small letters represent comparison among interaction means and capital letters are used for overall mean 
Table 6 Mean values ( \pm SE) of live percentage of spermatozoa collected from bulls of control and treatment groups on different weeks

\begin{tabular}{|c|c|c|c|c|}
\hline \multirow[t]{2}{*}{ Week of Treatments } & \multicolumn{3}{|l|}{ Group } & \multirow[t]{2}{*}{ Overall Mean } \\
\hline & A (Control) & B (Treatment 1) & $\mathrm{C}$ (Treatment 2) & \\
\hline 0 & $83.75 \pm 1.25 \mathrm{a}-\mathrm{d}$ & $77.50 \pm 1.44 \mathrm{~cd}$ & $76.25 \pm 1.25 \mathrm{~cd}$ & $79.17 \pm 1.20 B C$ \\
\hline 5 & $73.75 \pm 2.39 d$ & $77.50 \pm 1.44 \mathrm{~cd}$ & $75.00 \pm 2.04 \mathrm{~cd}$ & $75.42 \pm 1.14 C$ \\
\hline 6 & $76.25 \pm 2.39 \mathrm{~cd}$ & $77.50 \pm 1.44 \mathrm{~cd}$ & $75.00 \pm 2.04 \mathrm{~cd}$ & $76.25 \pm 1.09 B C$ \\
\hline 7 & $73.75 \pm 2.39 d$ & $77.50 \pm 1.44 \mathrm{~cd}$ & $76.25 \pm 2.39 \mathrm{~cd}$ & $75.83 \pm 1.20 \mathrm{C}$ \\
\hline 8 & $76.25 \pm 2.39 \mathrm{~cd}$ & $80.00 \pm 2.04 \mathrm{bcd}$ & $82.50 \pm 2.50 \mathrm{a}-\mathrm{d}$ & $79.58 \pm 1.44 \mathrm{BC}$ \\
\hline 9 & $76.25 \pm 2.39 \mathrm{~cd}$ & $83.75 \pm 2.39 a-d$ & $85.00 \pm 2.89 a-d$ & $81.67 \pm 1.78 \mathrm{AB}$ \\
\hline 10 & $73.75 \pm 2.39 d$ & $86.25 \pm 2.39 a b c$ & $85.00 \pm 2.89 a-d$ & $81.67 \pm 2.16 \mathrm{AB}$ \\
\hline 11 & $73.75 \pm 2.39 d$ & $90.00 \pm 2.04 a b$ & $92.50 \pm 1.44 a$ & $85.42 \pm 2.71 \mathrm{~A}$ \\
\hline 12 & $73.75 \pm 2.39 d$ & $93.75 \pm 1.25 a$ & $93.75 \pm 1.25 a$ & $87.08 \pm 2.98 \mathrm{~A}$ \\
\hline Mean & $75.69 \pm 0.85 B$ & $82.64 \pm 1.12 \mathrm{~A}$ & $82.36 \pm 1.33 \mathrm{~A}$ & \\
\hline
\end{tabular}

Means sharing similar letters in a row or in a column are statistically non-significant $(P>0.05)$. Small letters represent comparison among interaction means and capital letters are used for overall mean

groups (Table 7). Weekly analysis of variance showed that there was highly significant $(P<0.01)$ difference between treated and control group. Interaction between weeks and groups was also significant.

\section{Discussion}

This study was planned to examine the effect of supplementation of feed with flaxseed oil on libido and quality parameters of Nilli- Ravi buffalo bull's semen. Poly unsaturated fatty acids are mainly present in mammalian sperm which are not synthesized in body so they should be supplemented [31].

In the present study, libido in treated bulls was increased from 9 to 12 weeks of treatment. These values are in line with Estienne et al., [11] reported in boars. This increment in the libido may be due to production of higher amount of testosterone hormone. As testosterone is a steroid hormone and synthesized by cholesterol. Flaxseed oil having polyunsaturated fatty acids such as olic acids and linolinic acids which are major source of cholesterol [22]. In ram testosterone level increases in short day, but by supplementation of flaxseed oil same concentration is obtained in summer months (Baiomy and Mottelib, 20e409).

The volume of semen volume was increased in from 9 to 12 months of treatment as compared to control animals. Similarly, increase in semen volume was observed in goats [9], rams [5] and quails [4], Rooke et al., [26]. In contrary to present study Gliozzi et al., [14], Adeel et al., [1], Gholami et al., [13] reported non-significant increase in semen volume in chicken, rabbit, buffalo bulls and Holstein bulls respectively. Flaxseed contains high value of omega- 3 and omega- 6 fatty acids which acts as antioxidant.

Table 7 Mean values ( \pm SE) of sperm membrane functional integrity (\%) of control and treatment groups on different weeks

\begin{tabular}{lllll}
\hline Week of Treatments & Group & & & \\
\cline { 2 - 4 } & A (Control) & B (Treatment 1) & C (Treatment 2) & \\
\hline 0 & $52.50 \pm 1.44 \mathrm{hi}$ & $51.25 \pm 1.25 \mathrm{i}$ & $53.75 \pm 2.39 \mathrm{ghi}$ & $52.50 \pm 0.97 \mathrm{~F}$ \\
5 & $51.25 \pm 1.25 \mathrm{i}$ & $55.00 \pm 2.04 \mathrm{ghi}$ & $53.75 \pm 2.39 \mathrm{ghi}$ & $53.33 \pm 1.12 \mathrm{~F}$ \\
6 & $51.25 \pm 1.25 \mathrm{i}$ & $62.50 \pm 1.44 \mathrm{e}-\mathrm{h}$ & $57.50 \pm 3.23 \mathrm{f}-\mathrm{i}$ & $57.08 \pm 1.79 \mathrm{EF}$ \\
7 & $52.50 \pm 1.44 \mathrm{hi}$ & $66.25 \pm 1.25 \mathrm{c}-\mathrm{f}$ & $63.75 \pm 2.39 \mathrm{~d}-\mathrm{g}$ & $60.83 \pm 2.03 \mathrm{DE}$ \\
8 & $52.50 \pm 3.23 \mathrm{hi}$ & $68.75 \pm 1.25 \mathrm{a}-\mathrm{e}$ & $67.50 \pm 1.44 \mathrm{~b}-\mathrm{f}$ & $62.92 \pm 2.50 \mathrm{CD}$ \\
9 & $52.50 \pm 3.23 \mathrm{hi}$ & $72.50 \pm 1.44 \mathrm{a}-\mathrm{e}$ & $71.25 \pm 2.39 \mathrm{a}-\mathrm{e}$ & $65.42 \pm 3.04 \mathrm{BCD}$ \\
10 & $55.00 \pm 4.08 \mathrm{ghi}$ & $73.75 \pm 1.25 \mathrm{a}-\mathrm{d}$ & $71.25 \pm 1.25 \mathrm{a}-\mathrm{e}$ & $66.67 \pm 2.84 \mathrm{ABC}$ \\
11 & $55.00 \pm 2.04 \mathrm{ghi}$ & $77.50 \pm 1.44 \mathrm{ab}$ & $76.25 \pm 1.25 \mathrm{abc}$ & $69.58 \pm 3.23 \mathrm{AB}$ \\
12 & $55.00 \pm 2.04 \mathrm{ghi}$ & $78.75 \pm 1.25 \mathrm{a}$ & $78.75 \pm 1.25 \mathrm{a}$ & $70.83 \pm 3.47 \mathrm{~A}$ \\
Mean & $53.06 \pm 0.75 \mathrm{~B}$ & $67.36 \pm 1.59 \mathrm{~A}$ & $65.97 \pm 1.62 \mathrm{~A}$ & \\
\hline
\end{tabular}

Means sharing similar letters in a row or in a column are statistically non-significant $(P>0.05)$. Small letters represent comparison among interaction means and capital letters are used for overall means 
In present study overall mean values of mass activity were higher due to flax seed. Jafaroghli et al., [18] reported that supplementation with omega-3 fatty acids lead to significantly increase in mass activity of human semen. Improvement in mass activity of semen may be due to higher concentration and viablity sperm.

The importance of sperm motility has achieved a central role in the routine diagnosis of male fertility [3]. Motility percentage was significantly higher $\left(\begin{array}{ll}p & 0.01\end{array}\right)$ in treatment groups as compared to control group during 8-12 weeks of trial. Similar kind of results are reported in human [8], pigs [26], rams [5], goat [9, 28], rats [32] and boars [20]. Contrary to this study Adeel et al., [1] reported no improvement in motility of semen of buffalo bulls. Increased in motility percentage of semen may be due to fatty acids composition of sperm tail as reported by Mourvaki et al., [21] that flaxseed seed supplementation increased poly unsaturated fatty acids in rabbit sperm. This study showed that tail is major portion which is affected by supplementation of flaxseed supplementation. It can be assumed that poly unsaturated fatty acids present in flaxseed oil are involved in flagellar movement of sperm which in turn increases the motility percentage. The overall mean values of sperm concentration of treated groups were higher as compared to control. These results were similar in Stallion [29], goat [9], boars [11, 12], rams (Baiomy and Mottelib [5]) and men [12]. This increment in the sperm concentration in present study may be due to rapid spermatogenesis and antiapoptosis properties of supplementation of omega -3 fatty acids in feed. Supplementation of poly unsaturated fatty acids has positive effect on biosynthesis of prostaglandin and steroidogenesis. Poly unsaturated fatty acids have ability to affect the hypothalamic-pituitary axis and hormonal control of spermatogenesis.

The viability of sperm is considered as the useful parameters to differentiate between fertility and infertility conditions of males [15]. In the present study, lives sperm percentage was increased from 8 to 12 weeks of treatment. These findings are in close harmony as described by Rooke et al., [26], Dolatpanah et al., [9], Baiomy and Mottelib, [5], Mourvaki et al., [21],Gholami et al., [13], Al-Daraji et al., [4] and Esmaeili et al., [10]. The more number of live spermatozoa in ejaculates may be due to inhibition of apoptosis by action of poly unsaturated fatty acids as seen in culture off retinal photoreceptor and neuron [23].

The intact functional membrane of sperm is considered as the prerequisite for the sperm fertilizing ability due to successful acrosome reaction and binding to egg surface [7]. The functional integrity of sperm increased from 9 to 12 weeks of treatment in treated animals as compared to control. Similar to this study, comparable results were present in rabbit buck [21], buffalo bull [1], and in Holstein bulls Gholami et al., [13]. Increase in HOST positive spermatozoa was may be due to effect of poly unsaturated fatty acid on integrity of membrane [1].

\section{Conclusion}

It could be concluded that Supplementation of flaxseed oil has beneficial effect on semen quality parameter and libido of Nilli-Ravi buffalo bulls. This study further need to evaluate the effects of flax seed on cryopreservation and bull fertility.

\section{Acknowledgements \\ We are highly thankful to staff of semen production unit for their cooperation.}

\section{Authors' contributions}

First three authors played an active role in designing and conducting this trial. Similarly, parameter analysis, data analysis and manuscript preparation was performed by last two authors. All authors read and approved the final manuscript.

\section{Competing interests}

The authors have no conflict for the publication of this manuscript.

Received: 4 March 2016 Accepted: 31 May 2016

Published online: 01 July 2016

\section{References}

1. Adeel M, ljaz A, Aleem M, Rehman H, Yousaf MS, Jabbar MA. Improvement of liquid and frozen-thawed semen quality of Nili-Ravi buffalo bulls (Bubalusbubalis) through supplementation of fat. Theriogenology. 2009;71: 1220-5.

2. Adlercreutz H, Hockerstedt $K$, Bannwart C, Hamalainen E, Fotsis T, Bloigu S. Association between dietary fiber, urinary excretion of lignans and isoflavonic phytoestrogens and plasma non-protein bound sex hormone in relation to breast cancer. In: Bresciani F, King RJB, Lippman ME, Raynaud JP, editors. Progress in cancer research and therapy: hormones and cancer. 3rd ed. New York: Raven; 1988. p. 412.

3. Aitken RJ. Development of in vitro tests of human sperm function: a diagnostic tool and model system for toxicological analyses. Toxicol In Vitro. 1990;4:560-9.

4. Al-Daraji HJ, Al-Mashadani HA, Al-Hayani WK, Al-hassani AS, Mirza HA. Effect of dietary supplementation with different oils on productive and reproductive performance of quail. Inter J Poult Sci. 2010:9:656.

5. Baiomy AA, Mottelib AA. Effect of dietary flaxseed oil supplementation on reproductive performance of rams during summer. Anim Hyg Sust Livest Prod. 2009;3:1263-5.

6. Berndtson WE. Comparative reliability and sensitivity of different methods for assessing treatment effects on sperm production. Anim Reprod Sci. 2008;105:5-22.

7. Briskie JV. Spatiotemporal patters of sperm storage and last-male sperm precedence birds. Funct Ecol. 1996;10:375-83.

8. Conquer JA, Martin JB, Tummon I, Watson L, Tekpetey F. Effect of DHA supplementation on DHA status and sperm motility in asthenozoospermic males. Lipids. 2000;35:149-54.

9. Dolatpanah MB, Towhidi A, Farshad A, Rashidi A, Rezayazdi K. Effect of fish oil on semenquality of goats. Asian-Austr J AnimSci. 2008;21:29-34.

10. Esmaeili V, Shahverdi AH, Alizadeh AR, Alipour H, Chehrazi M. Saturated, omega- 6 and omega-3 dietary fatty acid effects on the characteristics of fresh, frozen- thawed semen and blood parameters in rams. Andrologia. 2012;46:42-9.

11. Estienne MJ, Harper AF, Crawford RJ. Dietary supplementation with a source of omega-3 fatty acids increases sperm number and the duration of ejaculation in boars. Theriogenology. 2008;70:70-6.

12. Fair S, Doyle DN, Diskin MG, Hennessy AA, Kenny DA. The effect of dietary n-3 polyunsaturated fatty acids supplementation of rams on semen quality and subsequent quality of liquid stored semen. Theriogenology. 2014;81:210-9. 
13. Gholami H, Chamani M, Towhidi A, Fazeli MH. Effect of feeding a docosahexaenoic acid-enriched nutriceutical on the quality of fresh and frozen-thawed semen in Holstein bulls. Theriogenology. 2010;74:1548-58.

14. Gliozzi TM, Zaniboni L, Maldjian A, Luzi F, Maertens L, Cerolini S. Quality and lipid composition of spermatozoa in rabbits fed DHA and vitamin E rich diets. Theriogenology. 2009;71:910-9.

15. Guzick DS, Overstreet JW, Factor-Litvak P, Brazil CK, Nakajima ST, Coutifaris C, Carson C, Cisneros SA, Steinkampf P, Hill MP, Xu JA, Vogel D. National Cooperative Reproductive Medicine Network. Sperm morphology, motility, and concentration in fertile and infertile men. N Engl J Med. 2001;345:138893.

16. Harris MA, Baumgard LH, Arns MJ, Webel SK. Stallion spermatozoa membrane phospholipids dynamics following dietary $n-3$ supplementation. Anim Reprod Sci. 2005;89:234-7.

17. Henney SR, Killian GJ, Deaver DR. Libido, hormone concentrations in blood plasma and semen characteristics in Holstein bulls. J Anim Sci. 1990;68:2784-92.

18. Jafaroghli M, Benemarb HA, Zamiric MJ, Khalilid B, Farshade A, Shadparvar AA. Effects of dietary $n-3$ fatty acids and vitamin $C$ on semencharacteristics, lipid composition of sperm and bloodmetabolites in fat-tailed Moghani rams. Anim Reprod Sci. 2014;147:17-24.

19. Jeyendran RS, Van darVen HH, Pelaez MP, Carbo BG, Zaneveld LJD. Development of an assay to access the functional integrity of human sperm membrane and its relationship to other semen characteristics. J Reprod Fert. 1984;70:219-28

20. Mitre $R$, Cheminade $C$, Allaume $P$, Legrand $P$, Legrand AB. Oral intake of shark liver oil modifies lipid composition and improves motility and velocity of boar sperm. Theriogenology. 2004;62:1557-66.

21. Mourvaki E, Cardinali R, Dal BA, Corazzi L, Castellini C. Effects of flaxseed dietary supplementation on sperm quality and on lipid composition of sperm subfractions and prostatic granules in rabbit. Theriogenology. 2009; 73:629-37.

22. Needleman P, Turk J, Kakshik BA, Morriso AR, Lefkowith JB. Arachidonic acid metabolism. Ann Rev Biochem. 1986;55:69-102.

23. Neuringer M, Anderson GJ, Conner WE. The essentiality of $n$-3fatty acids for the development and function of the retina and brain. Annu Rev Nutr. 1988;:8:517-41

24. Poulos A, Sharp P. Johnson D, White I, Fellenberg A. The occurrence of polyenoic fatty acids with greater than 22 carbon atoms in mammalian spermatozoa. Biochem J. 1986;240:891-5.

25. Robinson JJ, Ashworth CJ, Rooke JA, Mitchell LM, McEvoy TG. Nutrition and fertility in ruminant livestock. Anim Feed Sci Tech. 2006;126:259-76.

26. Rooke JA, Shao CC, Speake BK. Effects of tuna oil on lipid composition of pig spermatozoa and in vitro characteristics of semen. Reproduction. 2001; 121:315-22.

27. Salisbury GW, Van Demark NL, Lodge JR. Physiology of reproduction and artificial insemination of cattle. Shadara: C.B.S. Publishers and Distributers; 1985.

28. Samadian F, Towhidi A, Rezayazdi K, Bahreini M. Effects of dietary n-3 fatty acids on characteristics and lipid composition of ovine sperm. Animal. 2010; 4(12):2017-22.

29. Steven PB, Varnera DD, Loveb CC, Blancharda TL, Dayc BC, Wilson ME. Effect of feeding a DHA-enriched nutriceutical on the quality of fresh, cooled and frozen stallion semen. Theriogenology. 2005;63:1519-27.

30. Towhidi A, Samadian F, Rezayazdi K, Rostami F, Ghaziani F. Feeding n-3 fatty acid source improves semen quality by increasing $n 3 / n 6$ fatty acids ratio in sheep. Chicago: 10th World Conference on Animal Production; 2008. p. 65

31. Wathes DC, Abayasekara DR, Aitken RJ. Polyunsaturated fatty acids in male and female reproduction. Biol Reprod. 2007;77:190-201.

32. Yan L, Bai XL, Fang ZF, Che LQ, Xu SY, Wu D. Effect of different dietary omega-3/omega-6 fatty acid ratios on reproduction in male rats. Lipids Health Dis. 2013:12:33.

\section{Submit your next manuscript to BioMed Central and we will help you at every step:}

- We accept pre-submission inquiries

- Our selector tool helps you to find the most relevant journal

- We provide round the clock customer support

- Convenient online submission

- Thorough peer review

- Inclusion in PubMed and all major indexing services

- Maximum visibility for your research

Submit your manuscript at www.biomedcentral.com/submit
Biomed Central 